\title{
Educational curriculum design of Art Network Course in Colleges and Universities Based on Public Teaching Blackboard Platform
}

\author{
Xia Li
}

\author{
Jiangxi Technical College of Manufacturing, Nanchang, Jiangxi, 330095, China
}

Key words: Blackboard platform; Art Network Course; Characteristics; Network Plat

\begin{abstract}
With the development of the information society, the network as a tool for the modernization of college students has bring convenience to study. Blackboard network teaching platform which is an auxiliary mechanism for students creates an interactive teaching environment, improves the student's participation in the curriculum, enhance the autonomy of learning ,and enhance the student's art professional quality. The subject teaching of network course based on Blackboard platform has been practiced in many universities, but there is still little research on the teaching of the art course based on Blackboard platform. In the theoretical research, through the network and Blackboard platform, this work describes the characteristics of the art education courses and the status of art education in universities. How to make analysis on the art curriculum in the Blackboard platform more effectively, combining with the traditional teaching, injecting fresh blood to develop the art courses in universities.
\end{abstract}

\section{Introduction}

In today's society, the competition is becoming more and more intense, and the demand for innovative technical talents is obvious. The course teaching based on Blackboard network teaching platform conforms to the trend of teaching reform. The development of the network provides a good and stable technical support for the implementation of curriculum teaching. Through the Blackboard platform, teachers achieve online and offline network teaching, this breakthrough time, space-limited teaching mode, to facilitate the students to consolidate and learn knowledge, an increase of emotional exchanges between teachers and students to mobilize the students to self-study enthusiasm, enrich the students's life after school, expand the students 'knowledge of vision, but also greatly improve the students' artistic quality and creative skills.

Today, the teaching of art courses in colleges and universities still use the traditional teaching methods, this single teaching method has been unable to keep up with the university information technology education to bring students visual freshness and experience the excitement, in order to keep up with the trend of teaching information, Now a lot of college art education have been the initial implementation of information network teaching. With the development of information society, based on the Blackboard platform for the study of art courses as a convenient and effective way has gradually been the majority of teachers and students of all ages. It is the core of the course content, the teacher combines the specific curriculum content to design the curriculum with the characteristics of the curriculum, students based on their own learning level and ability to plan their own course content and progress. Teachers in the platform for the establishment of art courses must give full consideration to the needs of students and personality differences for students to set the real problem of learning the situation, to maximize the transfer of students to participate in curriculum and self-learning initiative, for example, students divided into collaborative group, to participate in the study of art courses, regular exhibitions and exchange activities, etc., so imperceptibly enhance students 'love of art courses, to enhance students' artistic accomplishment. Art courses are an open, autonomous, creative combination of the subject, and Blackboard platform modular structure is also artistic innovation, the modules can be used for students to learn, while students have to take the initiative to participate in the curriculum In the construction of the platform, the use of resources to explore their own resources. Therefore, based on the Blackboard platform for art courses in information technology teaching, through the platform module settings, teaching feedback, 
background tracking data, teachers and students to explore the exchange of students to the discipline of art discipline and love degree, to stimulate Students 'artistic thinking, to improve students' practical hands-on ability and artistic innovation thinking ${ }^{[1-3]}$.

\section{Principles of Artistic Education Network Course Design in Colleges and Universities}

\subsection{Follow the teaching rules of online courses}

The network course is based on the new educational thought,, in the traditional classroom content system, teaching syllabus, teaching reform on the basis of the provision of public teaching resources. The teaching of network course should not only make use of the characteristics of online media, but also reflect the of contemporary education reform. The teaching of online courses should follow the following set of principles ${ }^{[4]}$ :

(1) Cognitive autonomy: in the study of art courses, we should focus on training students as the main concept of learning, teaching design to follow the principle of individual autonomy, to provide students with a wide range of learning methods and art skills necessary skills software and authoring tools to achieve the autonomy of the learning process to explore the function;

(2) Collaborative interaction: collaborative learning can exercise the team's sense of teamwork, through communication with others to improve cognitive ability. The network teaching platform provides a strong technical support for the smooth development of collaborative learning, providing a good background for the interaction between students

(3) Open sharing: resource sharing is the biggest advantage of the network, so the design of network courses, to reflect the principle of sharing. In the process of decomposing difficult knowledge points, we can introduce rich dynamic learning resources through web links and so on, improve the openness of network curriculum structure and reflect the sharing of network resources.

\subsection{Follow the discipline of art education}

Creativity is the life of art works creation, today's art education advocates the development of students 'artistic abstract thinking, focusing on cultivating students' artistic thinking ability, so that students play artistic potential, improve the overall quality of artistic creativity, the cultivation of innovation ability as the core content of teaching, in a wide range of in-depth practice to promote the further development of innovative thinking, from a variety of training practice to select the most innovative unique design ideas. In the daily art curriculum appreciation and extracurricular specific practice, we should pay attention to the use of artistic thinking to inspire, in appreciation of the works at the same time, penetrate their feelings, carefully pondering, thin experience. Art courses of the creative process is not too many limitations, students have absolute autonomy, according to their own interests to create. If the lack of artistic creativity, then each work will appear much the same, it will gradually lose the value of appreciation, art courses will lose its own meaning. The study of art courses is full of vitality and vitality, because in the aesthetic thinking of art, everyone's life perception, learning experience, social practice experience is different, and these differences through the emotional way to feedback to their own works of art in. Therefore, teachers in the teaching of art courses, we should focus on guiding the development of students' creative thinking, respect for the creation of students, certainly the results of students, students to promote the art of learning initiative and enthusiasm ${ }^{[5]}$.

\section{The construction of Blackboard platform art course modular}

"Resources" and "activities" are the basis for the smooth implementation of art courses, teaching activities in order to carry out the basis for the good development of the students provided a guarantee. Therefore, based on the Blackboard platform for the establishment of art courses, need to pay more attention to assistive learning resources given in order to improve students' ability to participate in self-awareness and self-learning. Through the Blackboard platform, teachers can upload rich curriculum resources, according to teaching objectives, set up different teaching modules, each of the different modules according to the type of resources and display the form, in different ways to 
organize. The whole course consists of curriculum learning module, collaborative communication module, learning evaluation module composed of three parts ${ }^{[6]}$, as shown in Figure 1:

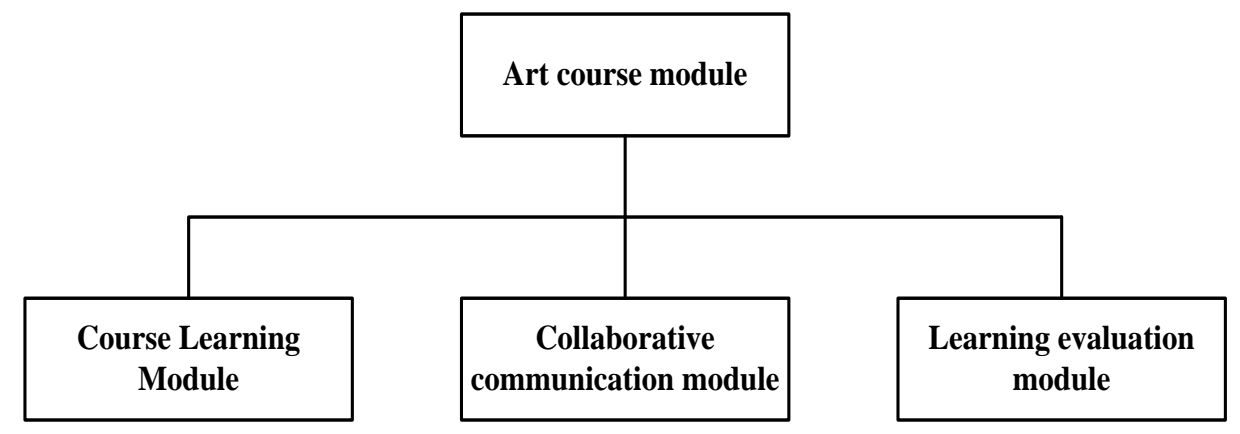

Fig.1 Course module composition diagram

\subsection{Construction and Application of Course Learning Module}

Course learning module is the most basic part of the network course, which consists of curriculum documents, curriculum information, operating area of three parts. Students can log in to the system directly through the school assigned account. According to their own music production level, points of interest and learning needs at any time to browse the contents of each section and download, so the new knowledge, so students can understand the knowledge can be more profound, change the teaching activities of the passive for the learning of the initiative, so that teachers improve the efficiency of teaching at the same time, students also enhance the ability of autonomous learning. In addition, you can also achieve extracurricular learning at any time, so as to meet the requirements of today's society fragmented learning. After the completion of the study at each section of the course, the teacher arranges the relevant practice of matching the knowledge of the chapter on the platform. The traditional course teaching is at the end of the course, the teacher arranges the corresponding homework, and then the student completes in the class and submits it to the teacher. Because the number of classes slightly, so the need for a class representative is responsible for homework, so you need to spend some time and manpower. And in the Blackboard platform directly on the layout and submission of work, the teacher through the score center direct statistical scores, eliminating the need for a lot of unnecessary waste time, in a fixed time before the cut-off point, students at any time upload operations, teachers can also be granted at any time correction ${ }^{[7]}$.

\subsection{Construction and Application of Collaborative Communication Module}

In the communication module, students can post in the discussion board, their own difficult problems recorded, so that members to exchange discussions. It can be divided into the following two sections: one is asynchronous exchange, so that students, teachers and students of the asynchronous exchange between the more convenient. For example: teachers in the forum posted on the topic of discussion in the classroom, to encourage each student in the forum to express their views and opinions, and actively participate in the discussion; students can be difficult questions in the forum, other students can show their own ideas to help Answer, or help teachers to help analyze; on the other hand is synchronized, teachers can also carry out online virtual lessons between after school. It is a real-time synchronization of the interaction, the teacher can be posted in the platform course information column synchronized virtual classroom opening time, requiring each student on time, active participation, it simulates the real classroom teaching. Teachers can answer questions in the virtual classroom, timely follow-up to enhance students' understanding of knowledge points. Virtual classroom break the space and time constraints, every student can participate in them. But the course time should be moderate, too long, easy for students to have a sense of ownership, thus affecting the learning interest and enthusiasm.

\subsection{Construction and Application of Learning Evaluation Module}

Learning evaluation is also an important part of web curriculum design. Reasonable evaluation can make the effective implementation of online courses, and students can play a role in promoting 
and stimulating, following the principles of process, diversity principles, the principle of development. Through the evaluation of students, teachers evaluation, curriculum content evaluation, can greatly improve the enthusiasm of students and teachers to participate in, to improve the content matching, to enhance the interaction between students and teachers, the entire learning evaluation structure shown in Figure $2^{[8]}$ :

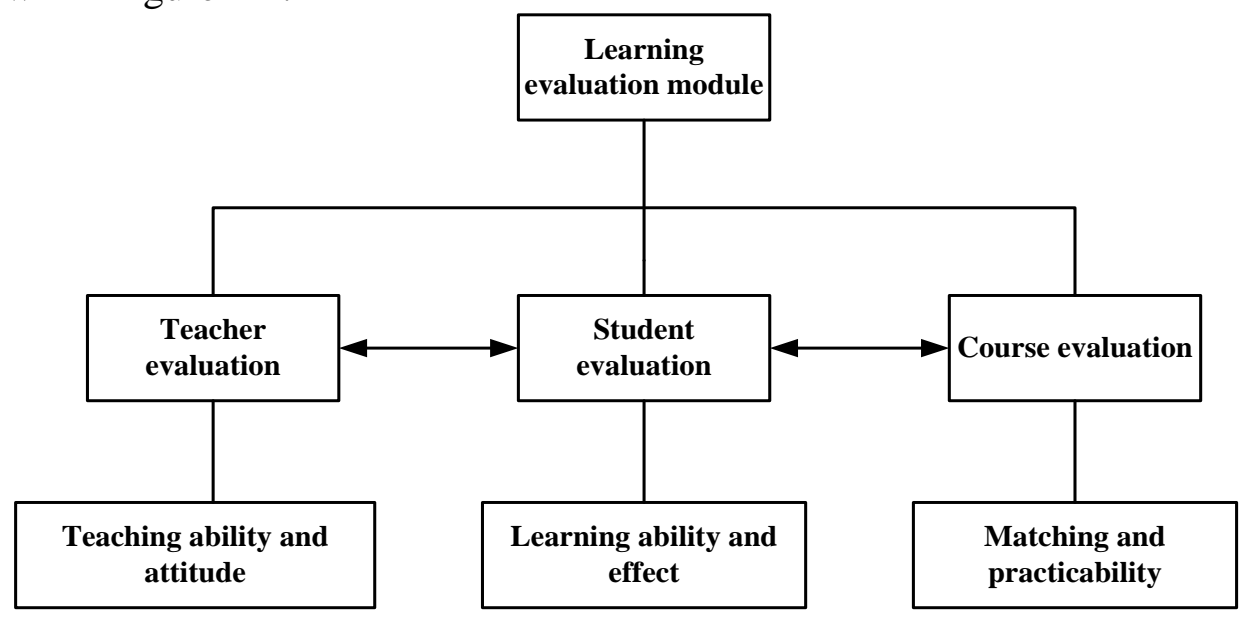

Fig.2 Learning evaluation structure

\section{Summary}

Blackboard network teaching platform for ease of use and rich teaching, communication, evaluation and other functions for the innovative art teaching philosophy, to carry out high-quality art teaching provides a strong material and technical conditions. The most important feature of the art network course teaching based on the Blackboard network teaching platform is that it breaks through the limitation of time and space, so that the classroom teaching and the internet can not be completely dependent on the relationship between teachers and students. Face-to-face teaching enriches students' access to knowledge. The art network course makes a useful supplement to the content of the classroom teaching, the teacher is no longer the monopoly of the music appreciation resource, but the instructor and the facilitator of the teaching process. Through the platform teachers can effectively manage the curriculum, to guide students from passive recipients into active participants, so as to build a student development-oriented art teaching model.

\section{References}

[1] Interships A C. Art Curating and Art Curatorship Internships - Department of Art History and Film Studies The University of Sydney[J]. Department of Art History Studies.

[2] Zhang F. Qn blackboard writing designing in art lessons of Middle School[J]. Journal of Yili Education College, 2003.

[3] Li Y. Discussion on the Arts of Blackboard Writing in Chinese Teaching[J]. Changzhou Institute of Light Industry Technology, 2005.

[4] O'Hara E. Art teachers' primer : forty-four assignments to art classes with eighteen blackboard diagrams and a frontispiece in color[J]. 1939.

[5] Hersch A E. Enhancing Blackboard utilization by continuing education faculty at Seneca College of Applied Arts and Technology: An action research study[J]. 2009.

[6] Uziak J. Acceptance of Blackboard Technology by Mechanical Engineering Students at the University of Botswana[J]. International Journal of Engineering Education, 2009, 25(25):131-137.

[7] Liu Y. Reflection and Prospect of Chemistry Teaching Art in China in Recent 30 Years[J]. Chinese Journal of Chemical Education, 2009.

[8] Betsy J. Cahill, Eve M. Adams. The couch and the blackboard: adding the 3 Rs of relationships, reactions (emotional), and reflection to the classroom[J]. Journal of Curriculum Studies, 2008, 
40(5):671-685. 